\title{
Agricultural Sustainability and Its Implications to the Horticulture Profession and the Ability to Meet Global Food Needs
}

\author{
E.T. York, Jr.' \\ Institute of Food and Agricultural Sciences, University of Florida, Gainesville, FL 32611
}

I am delighted to be invited to give the William A. (Tex) Frazier Lecture at this, the 88th Annual Meeting of the American Society for Horticultural Science. I never had the privilege of knowing Dr. Frazier personally, but I have heard many fine things about him and am honored to be associated with an activity that bears his name. Certainly, he has been one of the "giants" within the horticulture profession.

Let me add that I have known, worked with, respected, and admired many members of this Society over the years, including a number of your past presidents -F.S. Jamison, Russ Larson, John Carew, Henry Munger, Charles Hess, Al Krezdorn, and others. Your membership has made enormous contributions to improving the quality and quantity of food and other horticultural products that contribute so much to the quality of our life. I am delighted to be a guest of an organization whose members are such a vital part of our total society and who contribute so much to its improvement.

\section{Agricultural sustainability}

I have been asked to discuss the topic of agricultural sustainability and its implications to the horticulture profession and the global challenge of meeting the food needs of an ever-increasing population.

Sustainability concepts have been applied in some disciplines for many years. However, the term "sustainability" came into widespread use within the past 5 to 10 years when it began to be applied primarily to Third World development issues.

During the 1980s there emerged a growing, global concern over the manner in which many of the earth's natural resources were being used and whether, with such usage, the needs of a steadily increasing population could be sustained. To put this concern in perspective, however, it should be noted that the 20th century has seen remarkable progress in all areas of human endeavor, such as

Received for publication 21 July 1991. This paper was presented as the William A. (Tex) Frazier Lecture at the 88th Annual Meeting of the American Society for Horticultural Science, The Pennsylvania State Univ., University Park, 21 July 1991. 'Distinguished Service Professor.

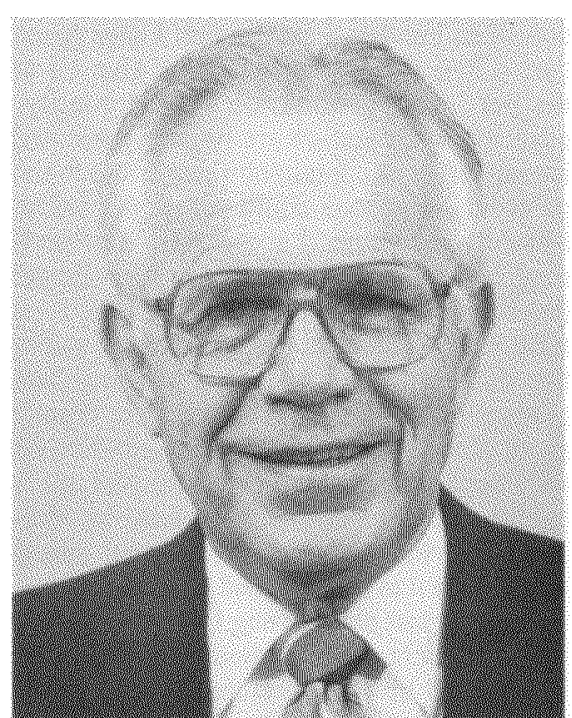

E.T. York, Jr.

education, medicine, industry, commerce, and agriculture. These advances have resulted in better living conditions, increased life expectancy, better educational opportunities and higher literacy rates, improved food supplies, better nutrition, and a general improvement in the quality of life for many (but not all) people around the word.

There is growing concern, however, that this progress may not be sustainable, because in making these advances, we have exhausted inordinate amounts of nonrenewable resources; we have used, misused, and abused many of our renewable natural resources; and we have contributed to the degradation of many facets of our environment in ways that could jeopardize the very future of humankind itself.

While reflecting on this progress, it should be noted that millions of people around the world have not enjoyed the advances and improvements in living quality to which I have alluded. The global community is, therefore, faced with the challenge of trying to include those who have been largely bypassed by human progress while, at the same time, sustaining the progress that has been made by others. Moreover, there is need to do this in ways that do not limit the ability of future generations to enjoy similar progress.

\section{Commission on environment and development}

This challenge was the motivation for the United Nations to establish the Commission on Environment and Development in 1983. This commission, chaired by Prime Minister Brundtland of Norway, was charged with the task of formulating long-term strategies to achieve sustainable global development by the year 2000 and beyond. In its 1987 report, Our Common Future, the commission defined sustainable development as "development that meets the needs of the present without jeopardizing the ability of future generations to meet their needs."

In applying these sustainability concepts to agriculture, a panel of the commission said, "Enduring food security will depend on a sustainable and productive resource base. The challenge facing governments and producers is to increase agricultural productivity and thus insure food security, while enhancing the productive capacity of this natural resource base in a sustainable manner."

The panel suggested the magnitude of this challenge in these words: "The next few decades present a greater challenge to the world food systems than they may ever face again. The effort to increase production in pace with unprecedented increase in demand, while retaining the essential ecological integrity of food systems, is colossal, both in its magnitude and complexity. Given the obstacles to be overcome, most of them manmade, it can fail more easily than it can succeed" (Food 2000, 1987).

\section{Trends in agricultural production}

Given the emphasis that the commission places on increasing global food production to meet growing needs, what about current trends in agricultural production and prospects for meeting such greater needs?

Before World War II, most of the increase in global agricultural production occurred as a result of expanding cultivated areas-as more production was needed, more land was brought into cultivation.

The post-World War II period has seen an unprecedented growth in agricultural production. On a global basis, agricultural output has grown at a rate of $\approx 2.5 \%$ per year (Fig. 1). Moreover, this growth in global 
production has generally exceeded the growth in opulation, resulting in an overall increase in per capita food production of $\quad \approx 0.6 \%$ annually between 1950 and 1986 .

This growth can be attributed not so much to an expansion in the total area under cultivation but rather to a greater productiyity resulting from the development and application of improved technology. This improvement in agricultural output was made possible not only by large production increases in industrialized regions, including Western Europe, North America, and Australia, but also in many Third World countries, especially Asia.

\section{Hunger and malnutrition remain serious problems}

With such growth, one might assume that global food supplies would be adequate; however, such statistics are often misleading. Africa, for example, has not shared in this improvement. In fact, for the past 20 years or so, per capita production of food in Africa has declined at the rate of $\approx 1 \%$ annually.

While average production in the other major regions of the world may reflect significant progress, there are extensive areas in Asia and Latin America that, for various reasons, have not enjoyed the progress necessary to accommodate basic food requirements. Moreover, even in regions that normally have good supplies, temporary shortages and even famine can result from war, floods, droughts, earthquakes, and other disasters that disrupt production.

The World Bank estimates that more than 700 million people, about one-third of the developing world population, do not receive enough calories for an active working life. Part of this difficulty grows out of a lack of purchasing power, which limits the ability of many of the world's hungry and malnourished to buy the food that is available.

\section{Future prospects for agricultural production}

If the sort of spectacular growth that has occurred in agricultural production in the last half of the 20th century has fallen short of meeting global food needs, what are the prospects of doing better-of more adequately accommodating these needs?

Current trends in food production do not offer great promise in this regard. Indeed, it is readily apparent that growth in agricultural production in much of the Third World is slowing significantly. For example, Fig. 2 indicates that in four of the six developingcountry regions (North and sub-Saharan Africa, and South and West Asia), the annual growth in per capita food production was less during the last 9 years (1977-86) of 1950 to 1986 than for the entire 36-year period. These data suggest that, in recent years, significant parts of the developing world are falling behind in efforts to meet growing needs for agricultural products.

Moreover, since 1986 there have been some sharp reversals in gains in cereal production.

Index $1976-78=100$

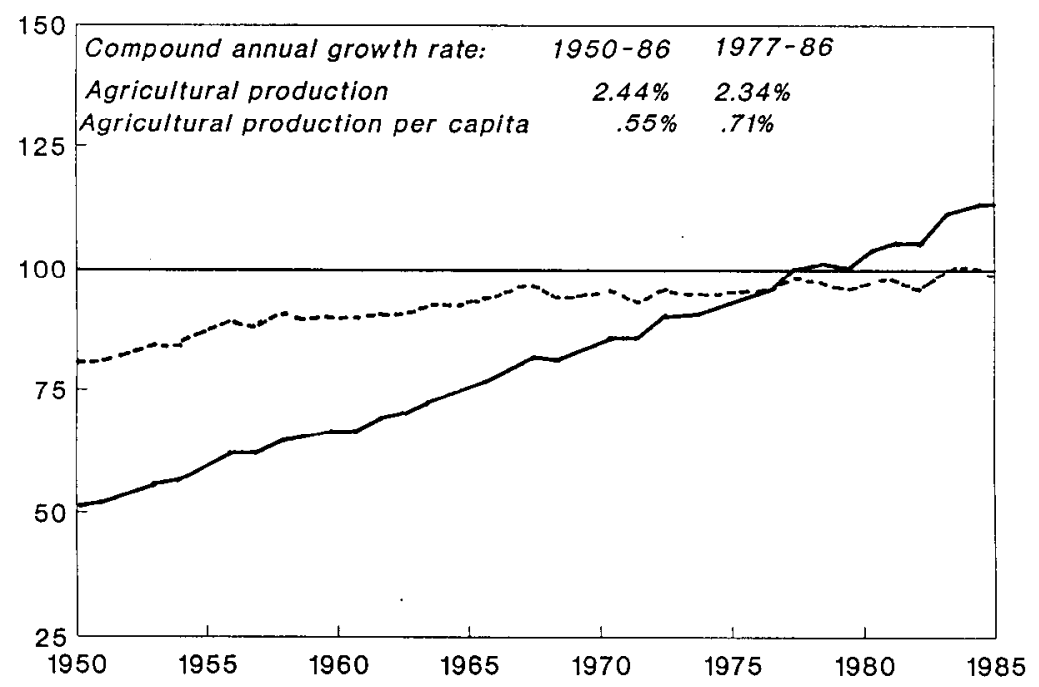

Fig. 1. Index of world agricultural production. (Source: U.S. Dept. of Agriculture World Indices of Agricultural and Food Production, 1977-86)

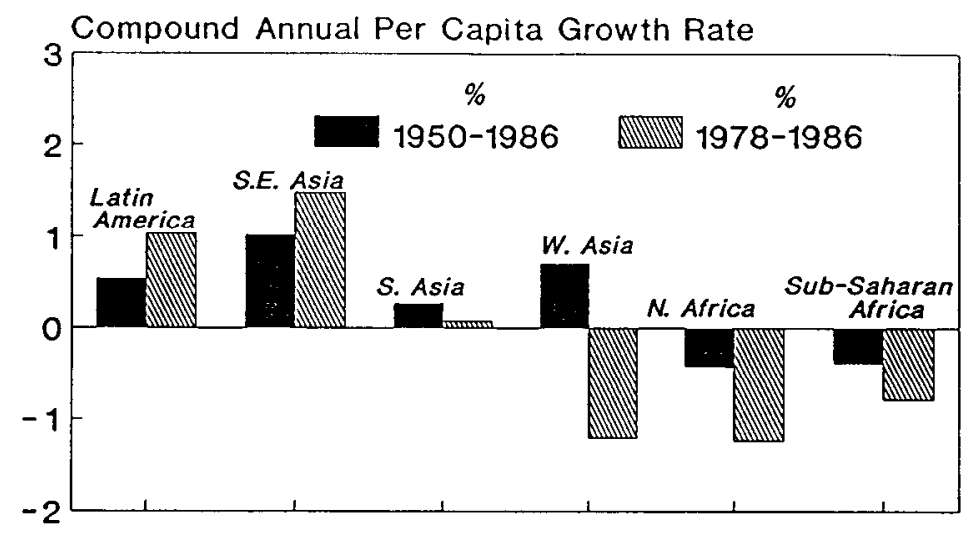

Fig. 2. Growth in agricultural production per capita in major regions of the Third World, 1950-86. (Source: U.S. Dept. of Agriculture World Indices of Agricultural and Food Production, 1977-66)

With only slight increases in cereal production globally in 1985-86, there were major declines in production in 1987-88. Brown (1988) indicates that in the mid-1980s, grain production plateaued in some of the world's most populous countries-India, Indonesia, Mexico, and China-countries that earlier had enjoyed tremendous growth in cereal production.

Herdt (1988) and others have pointed to the closing gap between actual national yields of major food commodities and potential yields, as reflected by work at research stations. In tests at the International Rice Research Institute in the Philippines, maximum yields of rice, for example, have apparently not increased since 1965 .

Many believe that the Green Revolution, which saw remarkable progress in cereal production in the least two to three decades, has essentially run its course and future advances in agricultural output will depend on further significant breakthroughs in the development of production technology through research.

\section{Concerns over future prospects}

These trends are not encouraging. Moreover, there are ominous dark clouds on the horizon that suggest the problem could become much worse. Below is some evidence to support this contention.

\section{Population growth}

The demand for food is steadily growing as some 90 million people are added to the global population annually. Significantly, more than $90 \%$ of this growth is occuring in the developing world, where serious problems of hunger and malnutrition already exist.

\section{Arable land}

Another cause for concern is the growing difficulty in expanding areas of productive arable land well suited for cultivation. It is estimated that from 1975 to 2000 , the area of cultivated land globally will expand only $4 \%$ while global population will increase $\approx 40 \%$. 
Environmental and natural resource degradation problems

A third and most disconcerting concern related to agriculture's ability to achieve continued improvement in productivity is the belief by many that we are, in fact, compromising the ability of future generations to meet their food needs by our current misuse of the natural resources on which agriculture depends.

Nothing in recent years has captured the attention and generated the concern of the world community more than the evidence of serious global environmental and natural resource degradation problems. These problems include the rapid destruction of tropical forests, the increasing concentration of atmospheric $\mathrm{CO}_{2}$ levels, and what some believe is the related global warming trend; the destruction of the ozone layer, as well as ozone pollution problems near the earth's surface; major problems of soil erosion; the contamination of underground aquifers, as well as lakes and streams; acid rain; and myriad other difficulties. Agriculture is viewed as a contributor to, as well as a victim of, some of these global environmental difficulties.

\section{Agricultural sustainability in the United States}

As a consequence of many of these environmental problems, agricultural sustainability has emerged as a very prominent issue in recent years within the United States. The focus, however, has not been nearly so much on meeting global food needs as on environmental and natural resource issues.

\section{Alternative agricultural systems}

In recent years, the concept of alternative agricultural systems has evolved within the United States. Such a term refers to agricultural systems that are "alternative" to socalled "conventional" systems.

The U.S. Dept. of Agriculture (USDA) has defined alternative agriculture as "a production system which avoids or largely excludes the use of synthetically compounded fertilizers, pesticides, growth regulators and livestock feed additives to the maximum extent feasible...." Increasingly, the term "alternative agriculture" is being used to include what is commonly referred to as organic farming, regenerative agriculture, and lowinput agricultural systems. In some circles, these alternative systems are being equated with sustainable agriculture. In fact, these terms are often used interchangeably. For example, Robert Rodale, the late head of the Rodale Institute of Pennsylvania, suggested that "sustainable was just a polite word for organic farming" (LISA, 1989).

\section{LISA (Low-Input Sustainable} Agriculture)

The term "LISA," advanced by the USDA, has gained widespread use as a form of alternative agriculture. Many have stressed, however, that it is inappropriate to attempt to treat low inputs as synonymous with sustainability. Using commonly accepted definitions, sustainable systems may or may not involve lower inputs. Lower usage of herbicides, for example, may result in higher inputs of labor. Some have also objected to the imprecise nature of the term "low inputs." What inputs? Low in relation to what? How low?

It would appear that the basic concept of sustainability is being significantly distorted by the term LISA and by the manner in which alternative systems, such as organic farming and regenerative agriculture, are being equated with sustainable agriculture. Such alternative systems tend to focus primary attention on the goal of reducing or eliminating the use of chemical inputs-advocating in their place the use of animal and green manures, crop rotations, and other related practices.

Many of these practices endorsed by alternative-agriculture advocates have wellrecognized merit. However, one must question the feasibility or practicality of generally incorporating many of these practices in U.S. commercial agricultural operations in ways that can achieve productivity and profitability objectives.

\section{National Research Council's report on alternative agriculture}

In 1989, the National Research Council (NRC) of the National Academy of Sciences published what has become a highly controversial document entitled "Alternative Agriculture" (National Resource Council, 1989). This report strongly exposes the merits of alternative agricultural approaches in contrast to conventional systems. Many individuals and groups have criticized the report, suggesting that it lacks the research information and background to justify its strong endorsement of alternative agricultural practices. Dean Kleckner, president, American Farm Bureau Federation, suggests that it gives "an inaccurate and too optimistic view of both the environmental and economic benefits of alternative agriculture" (Hileman, 1990).

The most comprehensive analysis and commentary of the NRC report was provided by the prestigious Council for Agricultural Sciences and Technology (CAST). More than 40 scientists provided commentaries on the report, and in June 1990, CAST representatives testified before a Joint Committee of Congress on the subject of alternative agriculture. CAST and its member scientists were generally complimentary of the goals of the NRC but highly critical of the techniques used in the study and the conclusions reached (CAST, 1990).

\section{More balanced and substantive approaches}

It should be noted that other individuals and organizations in the United States are approaching sustainable issues on a much more balanced and substantive basis by taking into account not only environmental issues, but also the productivity and economic viability of such systems.

The American Society of Agronomy, for example, defines a sustainable agriculture as "one that over the long term 1) enhances environmental quality and the resource base on which agriculture depends, 2) provides for basic human food and fiber needs, 3 ) is economically viable and 4) enhances the quality of life for farmers and society as a whole" (Weil, 1990). I think this is a very sound characterization of what sustainable agriculture is all about.

The Research Advisory Committee (RAC) of the U.S. Agency for International Development (USAID) addressed at some length the issue of low-input and sustainable agriculture. In response to the contention by some that modern or conventional agricultural systems were not sustainable, RAC said, "...Many modern agricultural production systems are not only sustainable, they have, in fact, created the fertility and resource base that sustains them. Some of the nation's most productive soils were once considered infertile and nonproductive ... . Most low input systems require high labor input and are often characterized by low output."

Michael Lipton, International Food Policy Research Institute (IFPRI). refers to the "dangerous nonsense of believing that one should strive for low input, high output agriculture" (Lipton, 1989).

John Ikerd, Univ. of Missouri, provides further perspective on this subject, suggesting that "... a sustainable agriculture must be made up of farming systems that are capable of maintaining their productivity and usefulness to society indefinitely..., In the long run, farming systems must be productive, competitive and profitable or they cannot be sustained economically. Also, systems must be ecologically sustainable or they cannot be profitable in the long run" (Ikerd, 1989).

It might be noted that USDA seems to be modifying its stance with regard to LISA. In a recent speech, Charles Hess, USDA Assistant Secretary for Research and Education, said this about sustainable agriculture: "Overall, agriculture is endeavoring to operate in an environmentally responsible fashion, while continuing to produce both economically and profitably. Sustainable agriculture is most emphatically not a return to the 'low tech' production methods of the '30s. On the contrary, it is the use of the very best in technology in a balanced, well-managed, economically viable, and environmentally responsible system" (Hess, 1991). To me, this is an excellent characterization of what sustainability is all about.

\section{Public concern about chemicals}

The great emphasis on alternative approaches to conventional farming methods results, in part, from the concern of many people about the potential harmful effects of chemicals. Unquestionably, problems have arisen from the use and, especially, the misuse of chemicals. Illnesses and even deaths have been caused by the use of pesticides, particularly by applicators who were not using the materials correctly. Certain pesticides have 
also caused damage to wildlife species, especially in earlier years when more persistent forms, such as DDT, were used. Furthermore, there is evidence that agricultural chemicals are finding their way into surface and subsurface water supplies.

How serious this problem may be is still subject to some conjecture. The fact that there may be minute quantities of chemicals in water supplies does not necessarily mean that such levels may pose problems to human health.

\section{Chemicals and human health}

If agriculture is to be sustainable, it must, among other things, provide safe and healthy food. There is growing evidence that the hazards of chemical residues on food are not nearly as great as some contend.

Sanford Miller, dean, Graduate School of Biomedical Science, Univ. of Texas Health Science Center, said, "The risk of pesticide residues to consumers is effectively zero." In referring to the Delaney Amendment, which could ban the use of any chemical that gives a positive test for cancer in rodentsno matter how low the concentration, Miller concluded, "If we apply Delaney [standards] to all foods, we would never get to die of cancer-we would all starve to death because we would have to ban all the foods we now eat" (Brookes, 1990).

Bruce Ames, professor of biochemistry and molecular biology, Univ. of California, Berkeley, suggests that $99.9 \%$ of all pesticide carcinogens now ingested by humans are natural; that is, they are generated as defense mechanisms within the plants themselves" (Brookes, 1990). He further reports on the level of natural carcinogens in various foods and says, "You get more carcinogens in a cup of coffee than in all the pesticide residues you absorb in a year" (Ames, 1991).

The U.S. Food and Drug Administration also contends that the risks from natural carcinogens in food is much greater than that from pesticides, suggesting that the public is worried about the wrong risk in their diets, partly because of the exaggerated news accounts of such scares as Alar in apples, cyanide in grapes, and dioxin in milk (Scheuplein, 1989).

Dr. Everett Koop, perhaps the most visible and respected U.S. Surgeon General in history, strongly opposed the recent "Big Green" initiative in California, saying that the banning of pesticides under this proposal would not have positive health effects and emphasizing that "public policy should be based on science, not on scare tactics" such as those used by the Big Green proponents (Brazil, 1990).

Serious harm has been done to agricultural enterprises by scare tactics such as those claiming that Alar on apples represented a serious threat to human health. The assertion by Ed Bradley on the television show "60Minutes" that "the most potent cancer-causing agent in our food supply is a substance (Alar) sprayed on apples to keep them on the tree longer and make them look better" (Bradley, 1989) proved to be totally unsub- stantiated and, in fact, ludicrous. Yet the Alar episode cost apple growers an estimated $\$ 100$ million or more in lost sales.

There is not much humor in situations like this-especially for those directly affected. Every now and then, however, someone comes along to inject a little humor into such matters and helps keep them in perspective. Recently, I came across an article by syndicated newspaper columnist Dave Barry entitled "Organic Gardening Concept Has Bugs In It" (Barry, 1991). Below are some excerpts from his column.

Spring is here, and as an educated, environmentally sensitive nutrition fanatic, you should definitely think about organically growing your own fruits and vegetables.

What do we mean when we say "organically grown" fruits and vegetables? Technically, we mean "fruits and vegetables with insects living in them. " Insects are an important source of protein, which is highly nutritious.

Look at bats. Bats eat a lot of insects, and they're extremely healthy. They can spend a wild night of flying around screeching and sucking blood from unwary victims, yet when they get back to the cave they still have enough "zing" left to sneak behind a stalactite for some hot sonar-enhanced sex ....

This is in stark contrast to the average American consumer, who rarely makes it through the monologue on "The Tonight Show." Why? Because the average American consumer is eating SUPERMARKET fruits and vegetables, which are known to contain-prepare to be alarmed-chemicals.

Of course not all chemicals are bad. Without chemicals such as hydrogen and oxygen, for example, there would be no way to make water, a vital ingredient in beer. But many of the fruits and vegetables that you buy in supermarkets have been saturated with a class of chemicals that are defined, technically, as "chemicals with long scary names, " such as "dioxyethylrickylucyBOOGABOOGAtide." These chemicals can be harmful. In one laboratory experiment, they were fed to a group of rats for six months, at the end of which 68 percent of the rats had become cigarette smokers.

Why do fruit and vegetable growers put such dangerous substances on your food? Actually, there's a very sensible explanation: They want to kill you.

No, seriously, they use chemicals for many good reasons, which will be thoroughly discussed about a week from now in an irate letter to the editor written by the attorney for the Fruit and Vegetable Growers Association.

Nevertheless, as a modem concerned paranoid consumer you should definitely grow your own food organically. We do this in our household. We have a tree in our yard, planted by the former owner, Bob, who told us that is was either a lime tree or a grapefruit tree, we forget which.

We never put chemicals on it, and every year it produces a nice crop of organic units the size of either large limes or small grapefruits with some kind of skin problem that looks like fruity leprosy. We monitor these units carefully until the exact moment when they have ripened to perfection, then we continue to monitor them as they fall on the ground and are consumed by gnats.

We've done this for two years now and have yet to notice any serious illness in the gnat community.

Yes, a sense of humor is helpful to put things in better perspective.

Despite widespread evidence that the health hazards of pesticides are often exaggerated, I would emphasize that it is imcumbent on those in agriculture to do everything possible to reduce and, to the extent possible, eliminate such potential hazards. As long as the public perceives there to be a problem, there is, indeed; a problem. More research is needed with chemical inputs to determine optimum levels of usage while avoiding undesirable consequences, if any, from such usage.

Such research can undoubtedly lead to reductions in the use of some pesticides through various approaches, including the continuing development of genetic resistance to many plant diseases and insects. Research can also help develop more effective biological approaches to pest control, as well as improve systems of integrated pest management.

Opportunities to reduce the use of fertilizers are not as apparent as with pesticides, since agricultural productivity is often correlated very directly with levels of fertilizer use. The Food and Agricultural Organization (FAO) of the United Nations estimates that from 1965 to $1976, \approx 55 \%$ of the increase in crop yields in developing countries could be attributed to fertilizers (FAO, 1981).

Research must continue to determine what levels of fertilizers should be used to meet the demands for agricultural products and give the producer adequate economic return, as well as ensure adequate food supplies at a reasonable cost to consumers. Where fertilizers contribute to environmental difficulties, such as nitrate or phosphate pollution of water sources, research must be accelerated to develop the means of overcoming these problems.

\section{An antiscience bais}

There seems to be a significant antiscience bias that characterizes much of the current alternative-agriculture movement. Such attitudes are truly unfortunate because the challenge of achieving sustainable agricultural systems rests, in large measure, with scientific institutions. Science is not the problem.

Indeed, science offers the key to achieving sustainable systems. Traditional agricultural systems were sustained indefinitely until greater demands were placed on such sys- 
terns by increasing population pressures. Research is essential to develop the technology needed to sustain these systems at levels above their natural steady state.

Research must focus increased attention on developing and applying the technology needed to achieve both the economic and ecological dimensions of sustainability. The planet Earth cannot achieve a sustainable agriculture and meet the ever-growing needs of people without the use of modem technology, including the appropriate usage of agricultural chemicals.

\section{Humanity in harmony with the environment}

A long-time friend and colleague, Orville Freeman, former U.S. Secretary of Agriculture, recently sent me a copy of a speech he had given at the World Future Society Conference dealing with the future of the biosphere. In his paper, "Humanity vs. Environment", Freeman addressed the basic dilemma of protecting our planet's environment while feeding its rapidly growing hungry population (Freeman, 1989). He referred to those who oppose the use of modem technology to improve food production for fear of contributing to environmental problems and responded to such arguments by emphasizing that humanity's need for food will not be met without the use of modem technology. I agree fully with such an assessment. And I would add that science and technology can and must help deal with those problems that might grow out of the use of such technology.

The issue is not one of humanity vs. the environment. This suggests some irreconcilable conflict that I do not believe exists. Perhaps a more appropriate title would be "Humanity in Harmony with the Environmerit." This is what we must strive to achieve-helping agriculture and, indeed, all of humanity to become truly in harmony with the environment.

The horticultural profession has a great challenge to contribute to such an objective. I commend you for what you have already done in this area and wish you well in future efforts.

It is a great pleasure to be with you.

\section{References}

National Research Council, National Academy of Science. 1989. Alternative agriculture. National Academy Press, Washington, D.C.

Ames, B. 1991. Lecture, Univ. of Florida, 5 June 1991.

Barry, D. 1991. Organic gardening concept has some bugs in it. Gainesville Sun, 17 Mar. 1991 Gainesville, Fla.

Bidinotto, R.J. 1990. The great apple scare. Readers Digest, Oct. 1990. p. 53-58.

Bradley, E. 1987. 60-Mintes. CBS-TV, 26 Feb. 1989.

Brazil, E. 1990. Another salvo at "Big Green." San Francisco Examiner, 26 Oct. 1990.

Brookes, W.T. 1990. The wasteful pursuit of zero risk. Forbes, 30 Apr. 1990. p. 161-172.

Brown, L.A. 1988. Worldwatch paper 85: The changing world food prospect: The nineties and beyond. Worldwatch International, Washington, D.C.
Council for Agricultural Science and Technology. 1990, Alternative agriculture-Scientists' review, July 1990. Council for Agricultural Science and Technology, Ames, Iowa.

Food and Agricultural Organization. 1981. Agriculture: Towards 2000. Food and Agricultural Organization of the United Nations, Rome.

Food 2000: Global policies for sustainable agriculture. 1987. Zed Books, London.

Freeman, O.L. 1989. The future of the biosphere-Humanity vs. the environment. World Future Society Conf., Washington, D. C., 17 July 1989.

Herdt, R. 1988. Increasing crop yields in developing countries. 1988 Amer. Agr. Econ. Assn. Mtg. The Rockefeller Foundation, New York.

Hess, C.E. 1991. Importance of ag research to U.S. and the world. Remarks at Auburn Univ., 4 Apr. 1991.

Hileman, B. 1990. Alternative agriculture. Chem. \& Eng. News, 5 Mar. 1990.

Ikerd, J.E. 1989. Sustainable agriculture. Annual Outlook Conf., U.S. Dept. Agr., Washington, D.C., 29 Nov. 1989.

Lipton, M. 1989. New strategic and successful examples for sustainable development in the Third World; International Policy Research Inst., Washington, D.C.

LISA: New concept or just a new name. Progressive Farmer, Oct. 1989.

Scheuplein, R.J. 1989. U.S. Food and Drug Administration, Washington, D.C.

WCED. 1987. Our common future. Report of the World Commission on Environment and Development. Oxford Press, New York.

Weil, R.R. 1990. Defining and using the concept of sustainable agriculture. J. Agron. Educ. 19:126-130. 